\title{
Response of Growing Rabbits to Diets Containing Different Levels of Protein and Mustard Seeds (Sinapisalba Linn)
}

\author{
Sh. A. M. Ibrahim (Corresponding author) \\ Animal Production Department, National Research Centre, Dokki, Giza, Egypt \\ Tel: 20-101-694-188Ｅ-mail: shawki_nrc@yahoo.com \\ H. A. A. Omer \\ Animal Production Department, National Research Centre, Dokki, Giza, Egypt \\ Tel: 20-114-089-312 E-mail: hamedomer2000@yahoo.com
}

A. A. Abedo

Animal Production Department, National Research Centre, Dokki, Giza, Egypt

Tel: 20-112-373-380Ｅ-mail: abedoaa@hahoo.com

F. A. F. Ali

Animal Production Department, National Research Centre, Dokki, Giza, Egypt

Tel: 20-101-461-585 E-mail: mf_ahmed@live.com

Received: March 24, 2011

doi:10.5539/jas.v4n1p190
Accepted: April 14, $2011 \quad$ Online Published: December 1, 2011

URL: http://dx.doi.org/10.5539/jas.v4n1p190

\begin{abstract}
A total number of 54 male growing New Zealand rabbits were used to study the effect of two different levels of ration protein supplemented with Mustard seeds(Sinapis alba Linn). Rabbits were classified into six equal groups $\left(\mathrm{G}_{1}-\mathrm{G}_{6}\right)$. The $1^{\text {st }}$ and $4^{\text {th }}$ groups received basal ration with $100 \%$ and $90 \%$ protein requirement and served as first and second control respectively. The $2^{\text {nd }}$ and the $3^{r d}$ groups received basal ration with $100 \%$ protein requirement supplemented withSinapisalba Linn at the level of 0.5 and $1.0 \%$, respectively. The $5^{\text {th }}$ and $6^{\text {th }}$ groups received basal ration with $90 \%$ protein requirement with Sinapisalba Linn at the level of 0.5 and $1.0 \%$, respectively. The low level of protein $(90 \%$ of protein requirement containing diet) significantly increased $(\mathrm{P}<0.05) \mathrm{DM}, \mathrm{OM}, \mathrm{CP}$, $\mathrm{CF}$ and NFE digestibility and TDN value compared to $100 \%$ of protein requirement. The high level of supplementation $(1 \%$ Mustard seeds) significantly $(\mathrm{P}<0.05)$ improved all nutrient digestibility coefficients and nutritive values. The $90 \%$ protein ration with $1 \%$ mustard seeds $\left(\mathrm{G}_{6}\right)$ showed the best digestion coefficients of DM, OM, CP, EE and NFE and TDN value. However, the $100 \%$ of protein requirement with $1 \%$ mustard seeds containing diet $\left(\mathrm{G}_{3}\right)$ showed the high value of DCP. Inclusion Mustard seeds at $1 \%$ in rabbit diets significantly $(\mathrm{P}<0.05)$ increased all nutrient digestibility and nutritive values compared to control diet. Inclusion Mustard seeds at $0.5 \%$ significantly $(\mathrm{P}<0.05)$ increased the $\mathrm{DM}$ and $\mathrm{EE}$ digestibility and total digestible nutrient compared to control diet. The interaction between the protein and mustard seeds levels significantly $(\mathrm{P}<0.05)$ increased the all nutrient digestibility coefficients (DM, OM, CP, CF, EE and NFE) and nutritive values (TDN and DCP). Inclusion Mustard seeds at $0.5 \%$ or $1 \%$ significantly $(\mathrm{P}<0.05)$ improved the final or weight, total body weight gain, average daily gain and feed conversion compared to control diet. On the other hand inclusion of Mustard seeds at $1 \%$ significantly $(\mathrm{P}<0.05)$ increased the total body weight gain and average daily gain by $24.3 \%$ while at $0.5 \%$ significantly $(\mathrm{P}<0.05)$ increased the total body weight gain and average daily gain by $14.5 \%$ compared to the control group. The $90 \%$ of protein with $1 \%$ mustard seeds recorded the best values of final weight, total body weight gain, average daily gain and feed conversion. The interaction between the protein and mustard seeds levels significantly $(\mathrm{P}<0.05)$ increased the final weight, weight gain, average daily gain and
\end{abstract}


feed conversion. Inclusion mustard seeds in rabbit diets clearly decreased the dressing percentages by increasing the level of mustard seeds in rabbit diets. Dietary $90 \%$ of protein requirements with $0.5 \%$ or $1 \%$ mustard seeds showed the higher value ofnet revenue, economical efficiency and relative economic efficiency, as well as the lower value of feed cost/ $\mathrm{kg}$ live body weight (LE).

Keywords: Mustard seeds, Rabbits, Growth performance, Digestibility, Carcass characteristics and economic evaluation

\section{Introduction}

Recently, it has found that some medicinal plants had some properties as growth enhancement. Some medicinal plants can be used as natural additives, tonic and restoratives in animal and poultry diets (Boulos, 1983), or to improve growth performance, immunity and the viability (El-Hindawyet al., 1996). Mustard oil is used as a flavoring in very low quantities (Koppelmanet al., 2007). Mustard green/leafy vegetables, when consumed regularly after steam cooking, would lower the risk of cardiovascular disease and cancer, advance nutrition research, and improve public health (Kahlonet al., 2008). Mustard oilhas been successfully applied inprophylactic of hyperacidity, gastric and duodenal ulcer (Gawronet al., 2005). Sinapisalba Linn (Commonly called yellow or white mustard) is an entomophilic species included in the Brassicaceae family, and their components have been reported to possess anticancer properties (Eskinet al., 2007). Sinapine is the effective component of Sinapisalbathat has a great potential in the field of antiageing drugs (Liu et al., 2006) and considered as an important natural antioxidant (Müller et al., 2001). Sinapisalba is a good candidate to use for immunotherapy purposes in future (Palomareset al., 2005). Bis-iodo phenol mustard has potential for use in future antibody-directed enzyme pro-drug therapy systems (Francis et al., 2002).

Low dietary protein requirements maycause imbalance in the body metabolism and growth performance. The hypothesis that sulfurcompounds has ability to repair the tissue defection protein of the cells. Sulfur mustard vesicants target thioredoxinreductase and that this may be an important mechanism mediating oxidative stress and tissue injury (Jan et al., 2010 and Gray et al., 2010). Sulfur is indispensable for synthesis of certain compounds-mainly sulphatedmucopolysaccharides in the body (Georgievskiiet al., 1982). The requirements of sulfur containing amino acids by monogastric animals is 3-4 percent of the feed protein, and the requirement for sulfur is 0.6-0.8 percent of the protein (Georgievskiiet al., 1982). The common albumin isolated from Sinapis alba seeds is composed of two disulfide-linked polypeptide chains of 39 and 88 amino acids as well as glutamine-rich large chain, proline-rich zein, a gliadin, and trypsin and alpha-amylase inhibitors isolated from the seeds of several monocotyledons, whose primary structures are reported by Menéndez-Arias et al. (1988). Mustard oil glycosides are derived from methionine, phenylalanine and tryptophan (Chavadejet al., 1994).

Tthe main objectives of this study was to evaluate the effect of Mustard seeds(Sinapisalba Linn) as feed additives in the diets of growing rabbits on feed utilization, growth performance, carcass characteristics and economic efficiency.

\section{Materials and Methods}

Fifty four male New Zealand White rabbits aged 5 weeks with an average body weight of $706 \pm 4.64 \mathrm{~g}$ were divided into six equal groups. The basal experimental diet was formulated and pelleted to cover the nutrient requirements of rabbits as a basal diet according to (NRC, 1977) as shown in (Table 1). The feeding period was extended for 70 days, and the experimental groups were classified as follow:

Group 1 basal diet with $100 \%$ protein requirement and served as control $\left(\mathrm{G}_{1}\right)$,

Group 2 basal diet with $100 \%$ protein requirement $+0.50 \%$ Mustard seeds $\left(\mathrm{G}_{2}\right)$,

Group 3 basal diet with $100 \%$ protein requirement $+1.00 \%$ Mustard seeds $\left(\mathrm{G}_{3}\right)$,

Group 4 basal diet with $90 \%$ protein requirement and served as control $\left(\mathrm{G}_{4}\right)$,

Group 5 basal diet with $90 \%$ protein requirement $+0.50 \%$ Mustard seeds $\left(\mathrm{G}_{5}\right)$ and

Group 6 basal diet with $90 \%$ protein requirement $+1.00 \%$ Mustard seeds $\left(\mathrm{G}_{6}\right)$.

Rabbits individually housed in galvanized wire cages $(30 \times 35 \times 40 \mathrm{~cm})$. Stainless steel nipples for drinking and feeders allowing recording individual feed intake for each rabbit were supplied for each cage. Feed and water were offered ad-libitum. Rabbits of all groups were kept under the same managerial conditions and were individually weighed, and feed consumption was individually recorded weekly during the experimental period.

At the end of the experimental period all rabbits in feeding trials were used in digestibility trials over period of 7 days to determine the nutrient digestibility coefficients and nutritive values of the tested diets. Feces were daily 
collected quantitatively. Feed intake of experimental rations and weight of feces were daily recorded. Representative samples were dried at $60^{\circ} \mathrm{C}$ for $48 \mathrm{hrs}$, ground and stored for later chemical analysis.

At the end of the experimental period, six representative rabbits from each treatment were randomly chosen and fasted for 12 hours before slaughtering according to Blasco et al. (1993) to determine the carcass measurements. Edible offal's (Giblets) included heart, liver, testes and kidneys were removed and individually weighed. Full and empty weights of digestive tract were recorded. Weights of internal and external offal's were calculated as percentages of slaughter weight $(\mathrm{SW})$. The 9,10 and $11^{\text {th }}$ ribs were frozen in polyethylene bags for later chemical analysis. The ribs of samples were dried at $60 \mathrm{C}^{\circ}$ for $24 \mathrm{hrs}$. The air-dried samples were analyzed for DM, EE and ash according to the A.O.A.C. (2000) methods, while CP percentage was determined by difference as recommended by O'Maryet al. (1979). Chemical analysis of experimental rations and feces were analyzed according to A.O.A.C (2000) methods. Neutral detergent fiber (NDF), acid detergent fiber (ADF) and acid detergent lignin (ADL) were also determined in the experimental rations according to Goering and Van Soest (1970).

Non fibrous carbohydrates (NFC), calculated according to Calsamigliaet al. (1995) using the following equation: $\mathrm{NFC}=100-\{\mathrm{CP}+\mathrm{EE}+\mathrm{Ash}+\mathrm{NDF}\}$. Compositions of the experimental rations have been done according to the NRC (1977) requirements as shown in (Table 1). Diets were offered pelleted at $4 \mathrm{~mm}$ diameter.

Economical efficiency of experimental diets was calculated according to the local market price of ingredients and rabbit live body weight as following:

Net revenue $=$ total revenue - total feed cost

Economical efficiency $(\%)=$ net revenue/ total feed cost $\%$.

Collected data were subjected to statistical analysis as two factors-factorial analysis of variance using the general linear model procedure of SPSS (1998). Duncan's Multiple Range Test (1955) was used to separate means when the dietary treatment effect was significant. Hemicellulose was calculated as the difference between NDF and ADF, while cellulose was calculated as the difference between ADF and ADL.Digestible energy (DE) was calculated according to Cheek (1987) as following:

$\mathrm{DE}(\mathrm{MJ} / \mathrm{kg} \mathrm{DM})=4.36-0.04 \times \mathrm{NDF} \%$.

\section{Results and discussion}

\subsection{Chemical analysis and cell wall constituents of the experimental diets}

Crude protein contents for the six rations used $\left(\mathrm{G}_{1}-\mathrm{G}_{6}\right)$ were 16.04, 16.11, 16.12, 14.48, 14.41 and $14.42 \%$, respectively (Table 2). These variations were related to differ in ingredients that used in ration formulations, also to study the effect of decreasing protein level on rabbit performance. The $90 \%$ of protein requirement containing diets showed slightly increase in cellulose contents while hemicellulose was slightly decreased. These data may suggest that alterations in metabolism involved in adaptation to a diet high in hemicellulose indicating an increased propensity for oxidative metabolism occurred in the intestine. Similar result was observed by Weber $e t$ al. (2010). While NDF, ADF and ADL values of the experimental rations showed insignificantly variations (Table 2).

\subsection{Nutrient digestibility and nutritive values of the experimental diets}

The $90 \%$ of protein requirements significantly $(\mathrm{P}<0.05)$ improved the digestibility coefficient values of $\mathrm{DM}, \mathrm{OM}$, CP, CF and NFE digestibility and TDN, while, EE digestibility was in the same trend (Table 3). In contrast, the $100 \%$ protein without feed additives $\left(\mathrm{G}_{1}\right)$ showed lowest values of DM, OM, CF and NFE digestibility coefficients and nutritive valued (TDN and DCP) (Table 4). Former suggest that when CP content is low the CF should be high and therefore the digestive efficiency in the small intestine appeared higher and must lead to improve the properties of digestion. Similar results obtained in rabbit by Milis and Liamadis (2008).

Mustard seeds at $1 \%$ in rabbit diets significantly $(\mathrm{P}<0.05)$ increased all nutrient digestibilities and nutritive values compared to control diet (Table 3 ). Mustard seeds at $0.5 \%$ significantly $(\mathrm{P}<0.05)$ increased the $\mathrm{DM}$ and EE digestibilities and total digestible nutrient compared to control diet (Table 3). These data may be due to the ability of Sinapisalba on the formation and/or release of antimicrobial substances as reported by Luciano et al. (2010). Also, may be due to the mustard oil enhancement of aerobic mesophilic and lactic acid bacteria as noticed by Lemay et al. (2002).

The $90 \%$ of protein requirement with $1 \%$ mustard seeds $\left(\mathrm{G}_{6}\right)$ showed the best digestion coefficients of $\mathrm{DM}, \mathrm{OM}$, $\mathrm{CP}, \mathrm{EE}$ and NFE and TDN value (Table 4). On the other hand $100 \%$ protein with $1 \%$ mustard seeds $\left(\mathrm{G}_{3}\right)$ showed the best value of DCP. The first result with low dietary protein means that the high dietary fiber 
promotes the digestion properties. Similar results wasobtained by (Milis and Liamadis 2008). The second result with high dietary protein may be due to the glycosides that are derived from methionine, phenylalanine, or tryptophanin mustard oil (Chavadejet al., 1994). On the other hand these results may be due to the ability of microorganisms to synthesize sulfur-amino acids that has been repeatedly demonstrated by sulfur (Georgievskiiet al., 1982). In other words these results in the two cases may be due to the aromatic isothiocyanates isolated from Sinapisalba containing phenethyl- benzyl- and benzoyl-groups might be useful in the development of novel preventive and therapeutic agents against diseases caused by harmful intestinal bacteria, as reported by Kim and Lee (2009).

Adding $0.5 \%$ or $1 \%$ mustard seeds showed insignificant effects on feed intakes of DM, TDN and DCP as well as $\mathrm{CP}$ intake (Table 5).This insignificant results may be indicate that mustard seeds is one of some dietary protein, whole grain, and fiber that promote satiety and either reduce energy absorption or stimulate energy expenditure, as explained by Astrupet al. (2010).

The interaction between the protein and mustard seeds levels significantly $(\mathrm{P}<0.05)$ increased the all nutrient digestibility coefficients (DM, OM, CP, CF, EE and NFE) and nutritive values (TDN and DCP) (Table 4). These significant results may be due to the high fiber related with the low protein level used (Milis and Liamadis 2008) as well as the volatile compounds of mustard hydrodistillates exhibited great potential of antibacterial activity as reported by Blazevićet al. (2010).

\subsection{Growth performance of the experimental groups}

The experimental diets of protein levels showed insignificant effects on final weight, total body weight gain, average daily gain and feed intake as DM, TDN, CP, DCP as well as feed conversion of DM, TDN, CP and DCP, respectively (Table 5). Inclusion of Mustard seeds in the rabbit diets at $0.5 \%$ or $1 \%$ significantly $(\mathrm{P}<0.05)$ improved the final weight, total weight gain, average daily gain and feed conversion compared to control diet (Table 5). These results indicate that mustard seeds may be able to be genetically modified to express high levels of beta-carotene, a precursor to vitamin A as reported by Chow et al. (2010).

Supplementation Mustard seeds at $1 \%$ level significantly $(\mathrm{P}<0.05)$ increased the total body weight gain and average daily gain by $24.3 \%$ while at $0.5 \%$ significantly $(\mathrm{P}<0.05)$ increased the total body weight gain and average daily gain by $14.5 \%$ compared to the control group (Table 6 ). The interaction between the protein and mustard seeds levels significantly $(\mathrm{P}<0.05)$ increased the final weight, weight gain, average daily gain and feed conversion (Table 6). These results may be due to the enzymatically synthesized natural antioxidant of mustard that has nutritional properties as cleared by Kanjilalet al. (1999). The $90 \%$ of protein requirement with $1 \%$ mustard seeds $\left(\mathrm{G}_{6}\right)$ recorded the best values of final weight, total weight gain, average daily gain and feed conversion (Table 6). In other words this result may due to detailed characterization of single antioxidant components of Sinapis alba seeds (i.e., polyphenols, carotenoids, chlorophylls, and ascorbic acid) as noticed by Salvatore et al. (2005).

\subsection{Carcass characteristics of the experimental groups}

The variety of protein or mustard seeds levels showed insignificant $(\mathrm{P}>0.05)$ effects on digestive tract weight, total inedible offal's weight, carcass weight and chemical analysis of the 9,10 and $11^{\text {th }}$ ribs (Table 7). Inclusion mustard seeds in rabbit diets clearly decreased the dressing percentages by increasing the level of mustard seeds in rabbit diets. This result may be due to the presence of some fatty acids in mustard oil that are not usually present in edible oils and fats that reduced calorie fats as reported by Kanjilalet al. (1999), and by Sengupta and Ghosh (2010) who reported that mustard oil had beneficial effects on energy balance. The protein or mustard seeds supplementation levels showed insignificant effects on digestive tract ( $\%$ of SW), liver, carcass weight and chemical analysis of the 9,10 and $11^{\text {th }}$ ribs (CP \& EE contents), while showed significantly $(\mathrm{P}<0.05)$ interaction on dressing percentages and chemical analysis of the 9,10 and $11^{\text {th }}$ ribs (DM \& ash contents), (Table 8). Rabbits that received $90 \%$ protein with $1 \%$ mustard seeds $\left(\mathrm{G}_{6}\right)$ recorded the best values of carcass weight. This result may be due to the mustard seed content of monounsaturated fatty acids that contribute to decelerating obesity and the metabolic syndrome as reported by Misraet al. (2010) and Eskinet al. (2007). Or may be due to the high resistance of Sinapisalba to trypsin digestion (González De La Peña et al., 1996).

\subsection{Economical evaluation}

The economical efficiency of dietary treatments is presented in Table (9). The profitability of using mustard seeds depends on upon the price of tested diets and the rabbit's growth performance. Lowering the dietary protein level from $100 \%$ to $90 \%$ ofrequirements decreased the total cost by $4.63 \%$. Dietary $90 \%$ of protein requirements with $0.5 \%$ or $1 \%$ mustard seeds showed the higher value ofnet revenue, economical efficiency and 
relative economic efficiency, as well as the lower value of feed cost/ $\mathrm{kg}$ live body weight (LE). These results was due to the high weight of carcass and growth performance values that deflexed the high nutritional value of mustard seeds levels of beta-carotene, a precursor to vitamin A as reported by Chow et al., (2010). Rabbits that received $90 \%$ protein with $1 \%$ mustard seeds $\left(\mathrm{G}_{6}\right)$ recorded the best values of carcass weight. Rabbits fed on diet $90 \%$ of protein requirements with $1 \%$ mustard seeds $\left(\mathrm{G}_{5}\right)$ diet recorded the highest value of relative economic efficiency $(155 \%)$ and the lowest value of feed cost/ $\mathrm{kg}$ live body weight $(5.23 \mathrm{LE})$. These results are agreement with those obtained by Ibrahim et al. (2009) when rabbits fed on two different levels of energy supplemented with Artemisia herba-alba, Matricariarecutita L. and Chrysanthemum coronarium as herb mixture.

\section{Conclusion}

Dietary $90 \%$ of protein requirements with $0.5 \%$ or $1 \%$ mustard seeds showed the high value ofnet revenue, economical efficiency and relative economic efficiency, the lower value of feed cost/ $\mathrm{kg}$ live body weight (LE) as well as the best parameters of digestibility coefficients and growth performance. Mustard seeds at $1 \%$ significantly $(\mathrm{P}<0.05)$ increased the total body weight gain and average daily gain by $24.3 \%$ while at $0.5 \%$ significantly $(\mathrm{P}<0.05)$ increased the total body weight gain and average daily gain by $14.5 \%$ compared to the control group.Our data suggest that mustard seeds can be considered effectively growth promoter for improving the utilization of low protein diet.

\section{References}

A.O.A.C. (2000). Official Methods of Analysis, $17^{\text {th }}$ ed. Association of Official Analytical Chemists, Washington, D.C, USA.

Astrup A, Kristensen M, Gregersen NT, Belza A, Lorenzen JK, Due A \& Larsen TM. (2010). Can bioactive foods affect obesity. Ann N Y Acad Sci. Mar, 1190: 25-41.

Blazević I, Radonić A, Mastelić J, Zekić M, Skocibusić M \& Maravić A. (2010). Hedge mustard (Sisymbriumofficinale): chemical diversity of volatiles and their antimicrobial activity. Chem. Biodivers. Aug., 7(8): 2023-2034.

Blasco A, Quhayaun J \& Masoscro G. (1993). Hormonization of criteria and terminology in rabbit meat research. World Rabbits Sciences, 1: 3-10.

Boulos, I. (1983). Medicinal plants of North Africa reference Publication. Inc. proc., $2^{\text {nd }}$ Con.Fac.Vit.Me. Cairo. Univ., Cairo, Egypt (1992).

Calsamiglia, S., Stem M.D \& Frinkins J.L. (1995). Effects of protein source on nitrogen metabolism in continuous culture and intestinal digestion in vitro. J. Anim. Sci., 73:1819.

Chavadej S, Brisson N, McNeil JN \& De Luca V. (1994). Redirection of tryptophan leads to production of low indoleglucosinolate canola. ProcNatlAcadSci U S A. Mar. 15, 91 (6): 2166-2170.

Cheeke, P.R. (1987). Rabbit feeding and nutrition. Academic Press. ISBN-10: 0121706052, ISBN-13: 978-01217060, p.376.

Chow J, Klein EY \& Laxminarayan R. (2010). Cost-effectiveness of "golden mustard" for treating vitamin A deficiency in India. PLoS One. Aug 10; 5 (8). 12046.

Duncan, D.B. (1955). Multiple Rang and Multiple F-Test Biometrics, 11: 1- 42.

El-Hindawy M.M, Tawfeek M.L \& Osman, S.H. (1996). Effect of some biological feed additives for different periods on performance of broiler chick. Zagazig J. Agri. Res., 23: 773-783.

Eskin NA, Raju J \& Bird RP. (2007). Novel mucilage fraction of Sinapisalba L. (mustard) reduces azoxymethane-induced colonic aberrant crypt foci formation in F344 and Zucker obese rats. Phytomedicine. Aug; 14 (7-8): 479-485. Epub 2006 Dec 22.

Francis RJ, Sharma SK, Springer C, Green AJ, Hope-Stone LD, Sena L, Martin J, Adamson KL, Robbins A, Gumbrell L, O'Malley D, Tsiompanou E, Shahbakhti H, Webley S, Hochhauser D, Hilson AJ, Blakey D \& Begent RH. (2002). A phase I trial of antibody directed enzyme prodrug therapy (ADEPT) in patients with advanced colorectal carcinoma or other CEA producing tumours. Br J Cancer, Sep 9, 87 (6): 600-607.

Gawron-Gzella A, Witkowska-Banaszczak E \& Dudek M. (2005). Herbs and herbal preparations applied in the treatment of gastric hyperacidity, gastric and duodenal ulcer in cigarette smokers. PrzeglLek, 62 (10): $1185-1187$. 
Georgievskii VI, Annenkov BN \& Samokhin VI. (1982). Studies in the agriculyural and food sciences “ Mineral Nutrition of Animals" USSR. Butterworths ISBN 0408107707.

Goering, H. K \& Van Soest, P.J. (1970). Forge fiber analysis (apparatus, reagents, procedure and some applications). Agric. Hand book 379, USDA, Washington, DC, USA. PUB ID: 101-564-920,

González De La Peña MA, Monsalve RI, Batanero E, Villalba M \& Rodríguez R. (1996). Expression in Escherichia coli of Sin a 1, the major allergen from mustard. Eur J Biochem., May 1, 237(3): 827-832.

Gray JP, Mishin V, Heck DE, Laskin DL \& Laskin JD. (2010). Inhibition of NADPH cytochrome P450 reductase by the model sulfur mustard vesicant 2-chloroethyl ethyl sulfide is associated with increased production of reactive oxygen species. ToxicolApplPharmacol, Sep 1. 247 (2): 76-82. Epub Jun 2.

Ibrahim, Sh. A. M., Abedo, A.A., Omer, H.A.A. \& Ali, F.A.F. (2009). Response of growing New Zealand White rabbits to diets containing different levels of energy and mixture of some medical plants. World Journal of Agricultural Science, 5 (5): 544-551.

Jan YH, Heck DE, Gray JP, Zheng H, Casillas RP, Laskin DL \& Laskin JD. (2010). Selective targeting of selenocysteine in thioredoxinreductase by the half mustard 2-chloroethyl ethyl sulfide in lung epithelial cells. Chem Res Toxicol., Jun 21, 23 (6): 1045-1053.

Kahlon TS, Chiu MC \& Chapman MH. (2008). Steam cooking significantly improves in vitro bile acid binding of collard greens, kale, mustard greens, broccoli, green bell pepper, and cabbage. Nutr Res. Jun, 28 (6): 351-357.

Kanjilal S, Prasad RB, Kaimal TN, Ghafoorunissa \& Rao SH. (1999). Synthesis and estimation of calorific value of a structured lipid-potential reduced calorie fat. Lipids. Oct, 34 (10): 1045-1055.

Kim MG \& Lee HS. (2009). Growth-inhibiting activities of phenethylisothiocyanate and its derivatives against intestinal bacteria. J. Food Sci., Oct, 74 (8): 467-471.

Koppelman SJ, Vlooswijk R, Bottger G, Van Duijn G, Van der Schaft P, Dekker J \& Van Bergen H. (2007). Development of an enzyme-linked immunosorbent assay method to detect mustard protein in mustard seed oil. $J$. Food Prot., Jan; 70(1): 179-183.

Lemay MJ, Choquette J, Delaquis PJ, Claude G, Rodrigue N \& Saucier L. (2002). Antimicrobial effect of natural preservatives in a cooked and acidified chicken meat model. Int. J. Food Microbiol. Oct 25; 78 (3): 217-26.

Liu L, Wang Y, Li H \& Ji Y. (2006). Study of distribution of sinapine in commonly used crude drugs from cruciferous plants. Se. Pu. Jan 24(1): 49-51.

Luciano FB, Belland J \& Holley RA. (2010). Microbial and chemical origins of the bactericidal activity of thermally treated yellow mustard powder toward Escherichia coli O157:H7 during dry sausage ripening. Int. $J$. Food Microbiol. Nov 24. Volume 145, Issue 1, 31 January 2011, Pages 69-76.

Menéndez-Arias L, Moneo I, Domínguez J \& Rodríguez R. (1988). Primary structure of the major allergen of yellow mustard (Sinapisalba L.) seed, Sin a I. Eur J Biochem., 177 (1): 159-166.

Milis Ch \& Liamadis D. (2008). Nutrient digestibility and energy value of sheep rations differing in protein level, main protein source and non-forage fiber source. J AnimPhysiolAnimNutr (Berl), Feb; 92 (1): 44-52.

Misra A, Singhal N \& Khurana L. (2010). Obesity, the metabolic syndrome, and type 2 diabetes in developing countries: role of dietary fats and oils. J. Am. Coll. Nutr., Jun; 29 (3 Suppl): 289-301.

Müller C, Agerbirk N, Olsen CE, Boevé JL, Schaffner U \& Brakefield PM. (2001). Sequestration of host plant glucosinolates in the defensive hemolymph of the sawfly Athaliarosae. J. Chem. Ecol. Dec., 27 (12): 2505-2516.

N.R.C. (1977). National Research Council.Nutrient requirements of rabbits, National Academy of Science, Washington, D.C.

O'Mary, C.C, Everett L.M \& Graig A.D. (1979). Production and carcass characteristics of Angus and Charolais x Angus steers. J. Anim. Sci., 48: 239.

Palomares O, Cuesta-Herranz J, Rodríguez R \& Villalba M. (2005). A recombinant precursor of the mustard allergen Sin a 1 retains the biochemical and immunological features of the heterodimeric native protein. Int Arch Allergy Immunol, May, 137 (1): 18-26. Epub Mar 21.

Salvatore S, Pellegrini N, Brenna OV, Del Rio D, Frasca G, Brighenti F \& Tumino R. (2005). Antioxidant characterization of some Sicilian edible wild greens. J. Agric. Food Chem., Nov 30, 53 (24): 9465-71. 
Sengupta A \& Ghosh M. (2010). Modulation of platelet aggregation, haematological and histological parameters by structured lipids on hypercholesterolaemic rats. Lipids. May; 45 (5): 393-400. Epub 2010 Apr 17.

SPSS. (1998). Statistical package for Social Sciences, Chicago, U.S.A.

Weber TE, Trabue SL, Ziemer CJ and Kerr BJ (2010).Evaluation of elevated dietary corn fiber from corn germ meal in growing female pigs. J Anim Sci., Jan; 88 (1):192-201. Epub 2009 Sep 25.

Table 1. Composition of the experimental diets $(\mathrm{kg} / \mathrm{ton})$

\begin{tabular}{|l|c|c|c|c|c|c|}
\hline \multirow{3}{*}{ Item } & \multicolumn{5}{|c|}{ Experimental diets } \\
\cline { 2 - 7 } & \multicolumn{3}{|c|}{$100 \%$} & \multicolumn{3}{c|}{$90 \%$} \\
\cline { 2 - 7 } & $\mathrm{G}_{1}$ & $\mathrm{G}_{2}$ & $\mathrm{G}_{3}$ & $\mathrm{G}_{4}$ & $\mathrm{G}_{5}$ & $\mathrm{G}_{6}$ \\
\hline Yellow corn & 230.00 & 230.00 & 230.00 & 270.00 & 270.00 & 270.00 \\
Barley grain & 50.00 & 50.00 & 50.00 & 50.00 & 50.00 & 50.00 \\
Wheat bran & 270.00 & 270.00 & 270.00 & 270.00 & 270.00 & 270.00 \\
Soybean meal 44\% CP & 150.00 & 150.00 & 150.00 & 120.00 & 120.00 & 120.00 \\
Alfalfa hay & 270.00 & 265.00 & 260.00 & 190.00 & 190.00 & 190.00 \\
Bean straw & ---- & ---- & ---- & 70.00 & 65.00 & 60.00 \\
Vit. \& Min. mixture* & 3.00 & 3.00 & 3.00 & 3.00 & 3.00 & 3.00 \\
Sodium chloride & 5.00 & 5.00 & 5.00 & 5.00 & 5.00 & 5.00 \\
DL-Methionine & 1.00 & 1.00 & 1.00 & 1.00 & 1.00 & 1.00 \\
Anti fungal agent & 1.00 & 1.00 & 1.00 & 1.00 & 1.00 & 1.00 \\
Lime stone & 10.00 & 10.00 & 10.00 & 10.00 & 10.00 & 10.00 \\
Ca- diphosphate & 10.00 & 10.00 & 10.00 & 10.00 & 10.00 & 10.00 \\
Mustard seed & ---- & 5.00 & 10.00 & --- & 5.00 & 10.00 \\
\hline Price, L.E**/Ton & 2094 & 2197 & 2301 & 1997 & 2112 & 2227 \\
\hline
\end{tabular}

* Vit. \& Min. mixture: Each kilogram of Vit. \& Min. mixture contains: 2000.000 IU Vit. A, 150.000 IU Vita. D, 8.33 g Vit. E, 0.33 gVit. K, 0.33 gVit. $B_{1}, 1.0$ gVit. $B_{2}, 0.33$ g Vit. $B_{6}, 8.33$ g Vit. $B_{5}, 1.7$ mg Vit. $B_{12}, 3.33$ g Pantothenic acid, $33 \mathrm{mg}$ Biotin, 0.83g Folic acid, $200 \mathrm{~g}$ Choline chloride, $11.7 \mathrm{~g} \mathrm{Zn}, 12.5 \mathrm{~g} \mathrm{Fe}, 16.6 \mathrm{mg} \mathrm{Se}, 16.6$ $\mathrm{mg} \mathrm{Co}, 66.7 \mathrm{~g} \mathrm{Mg}$ and $5 \mathrm{gMn}$.

** L. E: Livre Egyptiene (Egyptian Pound) $=0.18$ American dollars approximately

Table 2. Chemical analysis and cell wall constituents of the experimental diets

\begin{tabular}{|l|c|c|c|c|c|c|}
\hline \multirow{2}{*}{ Item } & \multicolumn{6}{|c|}{ Experimental diets } \\
\cline { 2 - 7 } & \multicolumn{3}{|c|}{$100 \%$} & \multicolumn{3}{c|}{$90 \%$} \\
& $\mathrm{G}_{1}$ & $\mathrm{G}_{2}$ & $\mathrm{G}_{3}$ & $\mathrm{G}_{4}$ & $\mathrm{G}_{5}$ & $\mathrm{G}_{6}$ \\
\cline { 2 - 7 } & 91.28 & 91.12 & 91.19 & 91.58 & 91.46 & 91.04 \\
Dry matter & 90.52 & 90.90 & 90.98 & 90.46 & 90.65 & 90.96 \\
Organic matter & 16.04 & 16.11 & 16.12 & 14.48 & 14.41 & 14.42 \\
Crude protein & 12.37 & 12.27 & 12.02 & 12.15 & 12.18 & 12.07 \\
Crude fiber & 2.74 & 2.65 & 2.73 & 2.58 & 2.63 & 2.68 \\
Ether extract & 59.37 & 59.87 & 60.11 & 61.25 & 61.43 & 61.79 \\
Nitrogen-free extract & 9.48 & 9.10 & 9.02 & 9.54 & 9.35 & 9.04 \\
Ash & 34.17 & 34.76 & 34.64 & 35.76 & 36.19 & 36.30 \\
NFC* & 2519 & 2528 & 2523 & 2516 & 2526 & 2520 \\
DE (MJ/kg DM)** & & & & & & \\
Cell wall constituents & 37.57 & 37.38 & 37.49 & 37.64 & 37.42 & 37.56 \\
NDF & 18.42 & 18.20 & 17.98 & 19.73 & 19.31 & 18.88 \\
ADF & 6.46 & 6.35 & 6.25 & 6.41 & 6.28 & 6.15 \\
ADL & 19.15 & 19.18 & 19.51 & 17.91 & 18.11 & 18.68 \\
Hemicellulose & 11.96 & 11.85 & 11.73 & 13.32 & 13.03 & 12.73 \\
Cellulose &
\end{tabular}

* Non fibrous carbohydrates (NFC), calculated using the following equation:NFC $=100-\{C P+E E+A s h+$ $N D F\} .{ }^{* *}$ Digestible energy (DE) was calculated as following: $D E(M J / \mathrm{kg} D M)=4.36-0.04 \times N D F \%$.

NDF: Neutral detergent fiber. ADF: Acid detergent fiber. ADL: Acid detergent lignin.

Hemicellulose $=N D F-A D F$. Cellulose $=A D F-A D L$. 
Table 3. Main effects of protein and supplementation levels on nutrient digestibility and nutritive values of the experimental diets

\begin{tabular}{|c|c|c|c|c|c|c|c|}
\hline \multirow{3}{*}{ Item } & \multicolumn{6}{|c|}{ Experimental diets } & \multirow{3}{*}{ SEM } \\
\hline & \multicolumn{2}{|c|}{ Protein levels } & \multirow[t]{2}{*}{ SEM } & \multicolumn{3}{|c|}{ Mustard seeds } & \\
\hline & $100 \%$ & $90 \%$ & & $0 \%$ & $0.5 \%$ & $1 \%$ & \\
\hline \multicolumn{8}{|l|}{ Digestibility coefficients } \\
\hline Dry matter (DM) & $79.08^{b}$ & $84.15^{\mathrm{a}}$ & 0.55 & $80.09^{b}$ & $81.72^{\mathrm{a}}$ & $83.03^{\mathrm{a}}$ & 0.55 \\
\hline Organic matter (OM) & $73.24^{\mathrm{b}}$ & $80.13^{\mathrm{a}}$ & 0.64 & $75.48^{\mathrm{c}}$ & $76.28^{\mathrm{b}}$ & $78.31^{\mathrm{a}}$ & 0.64 \\
\hline Crude protein $(\mathrm{CP})$ & $79.71^{\mathrm{b}}$ & $83.42^{\mathrm{a}}$ & 0.40 & $80.67^{\mathrm{b}}$ & $81.29^{\mathrm{b}}$ & $82.74^{\mathrm{a}}$ & 0.40 \\
\hline Crude fiber $(\mathrm{CF})$ & $44.12^{\mathrm{b}}$ & $62.39^{\mathrm{a}}$ & 1.81 & $47.54^{\mathrm{c}}$ & $53.41^{\mathrm{b}}$ & $58.82^{\mathrm{a}}$ & 1.81 \\
\hline Ether extract (EE) & 89.80 & 89.69 & 0.56 & $86.93^{b}$ & $91 .^{71 \mathrm{a}}$ & $90.61^{\mathrm{a}}$ & 0.56 \\
\hline Nitrogen-free extract (NFE) & $76.73^{\mathrm{b}}$ & $82.52^{\mathrm{a}}$ & 0.52 & $79.34^{\mathrm{b}}$ & $78.95^{\mathrm{b}}$ & $80.59^{\mathrm{a}}$ & 0.52 \\
\hline \multicolumn{8}{|l|}{ Nutritive values (\%) } \\
\hline Total digestible nutrient (TDN) & $69.55^{\mathrm{b}}$ & $75.67^{\mathrm{a}}$ & 0.58 & $71.20^{\mathrm{c}}$ & $72.27^{\mathrm{b}}$ & $74.36^{\mathrm{a}}$ & 0.58 \\
\hline Digestible crude protein (DCP) & $12.83^{\mathrm{a}}$ & $12.04^{\mathrm{b}}$ & 0.08 & $12.29^{\mathrm{b}}$ & $12.39^{\mathrm{b}}$ & $12.63^{\mathrm{a}}$ & 0.08 \\
\hline
\end{tabular}

$a, b$ and $c:$ Means in the same row within each treatment having different superscripts differ significantly $(P<0.05)$.

SEM, standard error of the mean.

Table 4. Effect of interactions between protein and supplementation levels on nutrient digestibility and nutritive values of the experimental diets

\begin{tabular}{|c|c|c|c|c|c|c|c|}
\hline \multirow{3}{*}{ Item } & \multicolumn{6}{|c|}{ Experimental diets } & \multirow{3}{*}{ SEM } \\
\hline & \multicolumn{3}{|c|}{$\begin{array}{c}100 \% \\
\text { Protein requirements }\end{array}$} & \multicolumn{3}{|c|}{$\begin{array}{c}90 \% \\
\text { Protein requirements }\end{array}$} & \\
\hline & $\mathrm{G}_{1}$ & $\mathrm{G}_{2}$ & $\mathrm{G}_{3}$ & $\mathrm{G}_{4}$ & $\mathrm{G}_{5}$ & $\mathrm{G}_{6}$ & \\
\hline \multicolumn{8}{|l|}{ Digestibility coefficients } \\
\hline Dry matter (DM) & $77.02^{\mathrm{c}}$ & $79.26^{\mathrm{b}}$ & $80.95^{b}$ & $83.17^{\mathrm{a}}$ & $84.18^{\mathrm{a}}$ & $85.11^{\mathrm{a}}$ & 0.55 \\
\hline Org & $71.42^{\mathrm{e}}$ & $72.44^{\mathrm{d}}$ & $75.87^{\mathrm{c}}$ & $79.54^{\mathrm{b}}$ & $80.12^{\mathrm{ab}}$ & $80.74^{\mathrm{a}}$ & 0.64 \\
\hline Crude $\mathrm{p}$ & $78.05^{\mathrm{c}}$ & $79.11^{\mathrm{c}}$ & $81.98^{b}$ & $83.29^{\mathrm{a}}$ & $83.47^{\mathrm{a}}$ & $83.49^{\mathrm{a}}$ & 0.40 \\
\hline Crude fiber (CF) & $35.62^{\mathrm{e}}$ & $42.96^{\mathrm{d}}$ & $53.78^{c}$ & $59.45^{\mathrm{b}}$ & $63.91^{\mathrm{a}}$ & $63.87^{\mathrm{a}}$ & 1.81 \\
\hline Ether $\mathrm{C}$ & $89.67^{\mathrm{bc}}$ & $91.47^{\mathrm{ab}}$ & $88.25^{\mathrm{c}}$ & $84.18^{\mathrm{d}}$ & $91.94^{\mathrm{a}}$ & $92.97^{\mathrm{a}}$ & 0.56 \\
\hline Nitrogen-free extra & $76.25^{\mathrm{d}}$ & $75.85^{\mathrm{d}}$ & $78.09^{\mathrm{c}}$ & $82.43^{\mathrm{ab}}$ & $82.04^{\mathrm{b}}$ & $83.09^{\mathrm{a}}$ & 0.52 \\
\hline \multicolumn{8}{|l|}{ Nutritive values } \\
\hline Total & $67.73^{f}$ & $68.89^{\mathrm{e}}$ & $72.03^{d}$ & $74.66^{\mathrm{c}}$ & $75.65^{b}$ & $76.69^{\mathrm{a}}$ & 0.58 \\
\hline Digestible crude $p$ & $12.52^{\mathrm{c}}$ & $12.75^{\mathrm{b}}$ & $13.21^{\mathrm{a}}$ & $12.06^{\mathrm{d}}$ & $12.03^{\mathrm{d}}$ & $12.04^{\mathrm{d}}$ & 0.08 \\
\hline
\end{tabular}

$a, b, c, d$, e and $f:$ Means in the same row having different superscripts differ significantly $(P<0.05)$.

SEM, standard error of the mean. 
Table 5. Main effects of protein and supplementation levels on growth performance of the experimental groups

\begin{tabular}{|c|c|c|c|c|c|c|c|}
\hline \multirow[t]{3}{*}{ Item } & \multicolumn{6}{|c|}{ Experimental diets } & \multirow[t]{3}{*}{ SEM } \\
\hline & \multicolumn{2}{|c|}{ proteinlevels } & \multirow[t]{2}{*}{ SEM } & \multicolumn{3}{|c|}{ Mustard seeds } & \\
\hline & $100 \%$ & $90 \%$ & & $0 \%$ & $0.5 \%$ & $1 \%$ & \\
\hline Initial weight, $\mathrm{g}$ & 707 & 705 & 4.64 & 705 & 706 & 708 & 4.64 \\
\hline Final weight, $g$ & 2232 & 2268 & 25.02 & $2072^{\mathrm{c}}$ & $2271^{\mathrm{b}}$ & $2408^{\mathrm{a}}$ & 25.02 \\
\hline Total body weight gain, $g$ & 1525 & 1563 & 24.26 & $1367^{\mathrm{c}}$ & $1565^{\mathrm{b}}$ & $1700^{\mathrm{a}}$ & 24.26 \\
\hline Average daily gain $\mathrm{ADG}, \mathrm{g}$ & 21.79 & 22.34 & 0.35 & $19.53^{\mathrm{c}}$ & $22.36^{\mathrm{b}}$ & $24.28^{\mathrm{a}}$ & 0.35 \\
\hline \multicolumn{8}{|l|}{ Feed intake as: } \\
\hline DM, g/day & 75.97 & 76.93 & 2.66 & 79.80 & 73.00 & 76.55 & 2.66 \\
\hline TDN, g/day & 52.80 & 58.37 & 1.96 & 56.90 & 52.70 & 57.15 & 1.96 \\
\hline CP, g/day & 12.17 & 11.07 & 0.40 & 12.12 & 11.05 & 11.70 & 0.40 \\
\hline DCP, g/day & 9.71 & 9.23 & 0.33 & 9.78 & 8.98 & 9.67 & 0.33 \\
\hline \multicolumn{8}{|c|}{ Feed conversion (g intake /g gain) of } \\
\hline DM & 3.52 & 3.47 & 0.13 & $4.07^{\mathrm{b}}$ & $3.25^{\mathrm{a}}$ & $3.15^{\mathrm{a}}$ & 0.13 \\
\hline TDN & 2.43 & 2.62 & 0.09 & $2.89^{\mathrm{b}}$ & $2.35^{\mathrm{a}}$ & $2.34^{\mathrm{a}}$ & 0.09 \\
\hline $\mathrm{CP}$ & 0.56 & 0.50 & 0.02 & $0.62^{\mathrm{b}}$ & $0.49^{\mathrm{a}}$ & $0.48^{\mathrm{a}}$ & 0.02 \\
\hline DCP & 0.45 & 0.42 & 0.02 & $0.50^{\mathrm{b}}$ & $0.40^{\mathrm{a}}$ & $0.40^{\mathrm{a}}$ & 0.02 \\
\hline
\end{tabular}

$a, b$ and $c:$ Means in the same row within each treatment having different superscripts differ significantly $(P<0.05)$.

DM: Dry matter.

TDN: Total digested nutrients.

CP: Crude Protein.

DCP: Digested Crude Protein.

Table 6. Effect of interactions between protein and supplementation levels growth on performance of the experimental groups

\begin{tabular}{|c|c|c|c|c|c|c|c|}
\hline \multirow{3}{*}{ Item } & \multicolumn{6}{|c|}{ Experimental diets } & \multirow{3}{*}{ SEM } \\
\hline & \multicolumn{3}{|c|}{$\begin{array}{c}100 \% \\
\text { Protein requirements }\end{array}$} & \multicolumn{3}{|c|}{$\begin{array}{c}90 \% \\
\text { Protein requirements }\end{array}$} & \\
\hline & $\mathrm{G}_{1}$ & $\mathrm{G}_{2}$ & $\mathrm{G}_{3}$ & $\mathrm{G}_{4}$ & $\mathrm{G}_{5}$ & $\mathrm{G}_{6}$ & \\
\hline Initial weight, $\mathrm{g}$ & 706 & 704 & 710 & 703 & 708 & 705 & 4.64 \\
\hline Final weight, $g$ & $2057^{\mathrm{d}}$ & $2242^{c}$ & $2396^{\mathrm{ab}}$ & $2087^{\mathrm{d}}$ & $2300^{\mathrm{bc}}$ & $2419^{\mathrm{a}}$ & 25.02 \\
\hline Total body weight gain, $g$ & $1351^{\mathrm{d}}$ & $1538^{\mathrm{c}}$ & $1686^{\mathrm{ab}}$ & $1384^{\mathrm{d}}$ & $1592^{\mathrm{bc}}$ & $1714^{\mathrm{a}}$ & 24.26 \\
\hline Average daily gain, $\mathrm{g}$ & $19.3^{\mathrm{d}}$ & $22.0^{\mathrm{c}}$ & $24.1^{\mathrm{ab}}$ & $19.8^{\mathrm{d}}$ & $22.7^{\mathrm{bc}}$ & $24.5^{\mathrm{a}}$ & 0.35 \\
\hline \multicolumn{8}{|l|}{ Feed intake as: } \\
\hline DM, g/day & 78.00 & 71.00 & 78.00 & 81.00 & 74.00 & 75.00 & 2.66 \\
\hline TDN, g/day & 53.00 & 49.00 & 56.00 & 60.00 & 56.00 & 58.00 & 1.96 \\
\hline $\mathrm{CP}, \mathrm{g} /$ day & 12.51 & 11.44 & 12.57 & 11.73 & 10.66 & 10.82 & 0.40 \\
\hline $\mathrm{DCP}, \mathrm{g} /$ day & 9.77 & 9.05 & 10.30 & 9.77 & 8.90 & 9.03 & 0.33 \\
\hline \multicolumn{8}{|c|}{ Feed conversion (g intake /g gain) of } \\
\hline $\mathrm{DM}$ & $4.04^{\mathrm{b}}$ & $3.23^{\mathrm{ab}}$ & $3.24^{\mathrm{ab}}$ & $4.09^{\mathrm{b}}$ & $3.26^{\mathrm{ab}}$ & $3.06^{\mathrm{a}}$ & 0.13 \\
\hline TDN & $2.75^{\mathrm{ab}}$ & $2.23^{\mathrm{a}}$ & $2.32^{\mathrm{a}}$ & $3.03^{\mathrm{b}}$ & $2.47^{\mathrm{ab}}$ & $2.37^{\mathrm{a}}$ & 0.09 \\
\hline $\mathrm{CP}$ & $0.65^{\mathrm{c}}$ & $0.52^{\mathrm{ab}}$ & $0.53^{\mathrm{abc}}$ & $0.59^{\mathrm{bc}}$ & $0.47^{\mathrm{ab}}$ & $0.44^{\mathrm{a}}$ & 0.02 \\
\hline DCP & $0.51^{\mathrm{c}}$ & $0.411^{\mathrm{abc}}$ & $0.43^{\mathrm{abc}}$ & $0.49^{\mathrm{bc}}$ & $0.39^{\mathrm{ab}}$ & $0.37^{\mathrm{a}}$ & 0.02 \\
\hline
\end{tabular}

$a, b, c$ and $d$ : Means in the same row having different superscripts differ significantly $(P<0.05)$.

SEM, standard error of the mean. 
Table 7. Main effects of protein and supplementation levels on dressing percentages, carcass cutsand chemical analysis of the 9,10 an $11^{\text {th }}$ ribs of the experimental groups

\begin{tabular}{|c|c|c|c|c|c|c|c|}
\hline \multirow{3}{*}{ Item } & \multicolumn{6}{|c|}{ Experimental diets } & \multirow[b]{3}{*}{ SEM } \\
\hline & \multicolumn{2}{|c|}{ Protein levels } & \multirow[b]{2}{*}{ SEM } & \multicolumn{3}{|c|}{ Mustard seeds } & \\
\hline & $100 \%$ & $90 \%$ & & $0 \%$ & $0.5 \%$ & $1 \%$ & \\
\hline $\begin{array}{l}\text { Slaughter weight (SW), g } \\
\text { Inedible offal's }\end{array}$ & 2505 & 2377 & 50.97 & 2375 & 2476 & 2472 & 50.97 \\
\hline Feet weight, $g$ & 83.00 & 83.00 & 0.00 & 83.00 & 83.00 & 83.00 & 0.00 \\
\hline Feet, $\%$ of SW & 3.32 & 3.54 & 0.08 & 3.52 & 3.40 & 3.36 & 0.08 \\
\hline Fur weight, g & 418 & 402 & 14.13 & $368^{\mathrm{b}}$ & $418^{\mathrm{ab}}$ & $444^{\mathrm{a}}$ & 14.13 \\
\hline Fur, $\%$ of SW & 16.69 & 16.80 & 0.37 & $15.39^{\mathrm{c}}$ & $16.87^{\mathrm{b}}$ & $17.98^{\mathrm{a}}$ & 0.37 \\
\hline Digestive tract weight, $g$ & 319 & 301 & 7.05 & 303 & 322 & 305 & 7.05 \\
\hline Digestive tract, $\%$ of SW & 12.75 & 12.71 & 0.26 & 12.74 & 13.14 & 12.31 & 0.26 \\
\hline Head weight, $\mathrm{g}$ & $152^{\mathrm{a}}$ & $138^{\mathrm{b}}$ & 2.67 & 149.2 & 142.5 & 144 & 2.67 \\
\hline Head, $\%$ of SW & 6.09 & 5.85 & 0.10 & $6.29^{a}$ & $5.80^{\mathrm{b}}$ & $2.82^{\mathrm{b}}$ & 0.10 \\
\hline Lungs weight, $g$ & 15.78 & 14.44 & 0.53 & 14.17 & 16.33 & 14.83 & 0.53 \\
\hline Lungs, $\%$ of SW & 0.63 & 0.61 & 0.02 & 0.60 & 0.66 & 0.60 & 0.02 \\
\hline Total inedible offal's weight, $g$ & 988 & 938 & 20.41 & 917 & 982 & 991 & 20.41 \\
\hline Total in edible, $\%$ of SW & 39.49 & 39.49 & 0.45 & 38.54 & 39.87 & 40.07 & 0.45 \\
\hline Edible offal's & & & & & & & \\
\hline Liver weight, $g$ & 68.44 & 63.44 & 2.43 & 62.17 & 63.67 & 72.00 & 2.43 \\
\hline Liver, $\%$ of SW & 2.73 & 2.66 & 0.07 & $2.62^{\mathrm{ab}}$ & $2.55^{\mathrm{b}}$ & $2.92^{\mathrm{a}}$ & 0.07 \\
\hline Heart weight, $g$ & 8.89 & 7.89 & 0.40 & 8.00 & 7.83 & 9.33 & 0.40 \\
\hline Heart, $\%$ of SW & 0.35 & 0.34 & 0.02 & 0.33 & 0.32 & 0.38 & 0.02 \\
\hline Kidneys weight, g & 18.56 & 15.78 & 1.06 & 15.67 & 17.00 & 18.83 & 1.06 \\
\hline Kidneys, $\%$ of SW & 0.74 & 0.66 & 0.04 & 0.66 & 0.68 & 0.76 & 0.04 \\
\hline Testes weight, $\mathrm{g}$ & 10.89 & 10.44 & 0.66 & $8.33^{\mathrm{b}}$ & $11.83^{\mathrm{a}}$ & $11.83^{\mathrm{a}}$ & 0.66 \\
\hline Tests, $\%$ of SW & 0.44 & 0.43 & 0.02 & $0.36^{\mathrm{b}}$ & $0.48^{\mathrm{a}}$ & $0.48^{\mathrm{a}}$ & 0.02 \\
\hline Total edible offal's weight, $\mathrm{g}$ & 106.8 & 97.6 & 3.71 & $94.17^{\mathrm{b}}$ & $100.33^{\mathrm{ab}}$ & $112.00^{\mathrm{a}}$ & 3.71 \\
\hline Total edible offal's, $\%$ of SW & 4.26 & 4.11 & 0.10 & $4.00^{\mathrm{b}}$ & $4.04^{\mathrm{b}}$ & $4.53^{\mathrm{a}}$ & 0.10 \\
\hline Carcass weight (CW1), g & 1409 & 1342 & 32.17 & 1363 & 1395 & 1369 & 32.17 \\
\hline Carcass weight including edible offal's (CW2) & & & & & & & \\
\hline $\begin{array}{c}\text { Dressing percentages }(D P) \% \\
\mathrm{DP}^{1}(\mathrm{CW} 1 / \mathrm{SW})\end{array}$ & 1516 & 1440 & 34.60 & 1458 & 1495 & 14.81 & 34.60 \\
\hline $\mathrm{DP}^{2}(\mathrm{CW} 2 / \mathrm{SW})$ & 56.26 & 56.42 & 0.47 & $57.52^{\mathrm{a}}$ & $56.09^{\mathrm{ab}}$ & $55.41^{\mathrm{b}}$ & 0.47 \\
\hline & 60.51 & 60.45 & 0.45 & 61.38 & 60.13 & 59.93 & 0.45 \\
\hline Chemical analysis of the 9,10 and $11^{\text {th }}$ ribs & & & & & & & \\
\hline Dry matter & 31.62 & 32.79 & 0.82 & 33.21 & 33.19 & 30.22 & 0.82 \\
\hline Chemical composition on DM basis & & & & & & & \\
\hline Crude protein $(\mathrm{CP})$ & 58.97 & 63.45 & 1.17 & 60.97 & 61.63 & 61.02 & 1.17 \\
\hline Ether extract (EE) & 33.38 & 28.51 & 1.30 & 31.56 & 29.87 & 31.41 & 1.30 \\
\hline Ash & 7.65 & 8.05 & 0.22 & $7.48^{b}$ & $8.50^{\mathrm{a}}$ & $7.57^{\mathrm{ab}}$ & 0.22 \\
\hline
\end{tabular}

$a, b$ and $c:$ Means in the same row within each treatment having different superscripts differ significantly $(P<0.05)$.

SEM, standard error of the mean. 
Table 8. Effect of interactions between protein and supplementation levels on dressing percentages, carcass cutsand chemical analysis of the $9,10 \mathrm{an} 11^{\text {th }}$ ribs of the experimental groups

\begin{tabular}{|c|c|c|c|c|c|c|c|}
\hline \multirow[b]{3}{*}{ Item } & \multicolumn{6}{|c|}{ Experimental diets } & \multirow[b]{3}{*}{ SEM } \\
\hline & \multicolumn{3}{|c|}{$\begin{array}{c}100 \% \\
\text { Protein requirements }\end{array}$} & \multicolumn{3}{|c|}{$\begin{array}{c}90 \% \\
\text { Protein requirements }\end{array}$} & \\
\hline & $\mathrm{G}_{1}$ & $\mathrm{G}_{2}$ & $\mathrm{G}_{3}$ & $\mathrm{G}_{4}$ & $\mathrm{G}_{5}$ & $\mathrm{G}_{6}$ & \\
\hline \multicolumn{8}{|l|}{ Inedible offal's } \\
\hline Feet weight, g & 83.00 & 83.00 & 83.00 & 83.00 & 83.00 & 83.00 & 0.00 \\
\hline Feet, $\%$ of SW & 3.26 & 3.35 & 3.33 & 3.77 & 3.35 & 3.39 & 0.08 \\
\hline Fur weight, $g$ & $419^{\mathrm{a}}$ & $391^{\mathrm{ab}}$ & $444^{\mathrm{a}}$ & $316^{\mathrm{b}}$ & $445^{\mathrm{a}}$ & $444^{\mathrm{a}}$ & 14.13 \\
\hline Fur, $\%$ of SW & $16.46^{\mathrm{bc}}$ & $15.80^{\mathrm{c}}$ & $17.80^{\mathrm{ab}}$ & $14.34^{\mathrm{d}}$ & $17.95^{\mathrm{a}}$ & $18.13^{\mathrm{a}}$ & 0.37 \\
\hline Digestive tract weight, $g$ & $355^{\mathrm{a}}$ & $307^{\mathrm{abc}}$ & $316^{\mathrm{ab}}$ & $271^{\mathrm{c}}$ & $337^{\mathrm{a}}$ & $294^{\mathrm{bc}}$ & 7.05 \\
\hline Digestive tract, $\%$ of SW & 13.16 & 12.41 & 12.67 & 12.30 & 13.59 & 12.00 & 0.26 \\
\hline Head weight, $g$ & $159^{\mathrm{a}}$ & $150^{\mathrm{ab}}$ & $149^{\mathrm{ab}}$ & $140^{\mathrm{b}}$ & $135^{\mathrm{b}}$ & $139^{\mathrm{b}}$ & 2.67 \\
\hline Head, $\%$ of SW & $6.25^{\mathrm{ab}}$ & $6.06^{\mathrm{abc}}$ & $5.97^{\mathrm{abc}}$ & $6.35^{\mathrm{a}}$ & $5.45^{\mathrm{c}}$ & $5.68^{\mathrm{bc}}$ & 0.10 \\
\hline Lungs weight, $\mathrm{g}$ & $14^{\mathrm{bc}}$ & $17^{\mathrm{ab}}$ & $17^{\mathrm{a}}$ & $15^{\mathrm{abc}}$ & $16^{\mathrm{ab}}$ & $13^{\mathrm{c}}$ & 0.53 \\
\hline Lungs, $\%$ of SW & $0.55^{\mathrm{b}}$ & $0.69^{\mathrm{a}}$ & $0.68^{\mathrm{a}}$ & $0.68^{\mathrm{a}}$ & $0.65^{\mathrm{a}}$ & $0.53^{\mathrm{b}}$ & 0.02 \\
\hline Total inedible offal's weight, $g$ & $1010^{\mathrm{a}}$ & $948^{\mathrm{a}}$ & $1009^{\mathrm{a}}$ & $825^{\mathrm{b}}$ & $1016^{\mathrm{a}}$ & $973^{\mathrm{a}}$ & 20.41 \\
\hline Total in edible, $\%$ of SW & $39.69^{\mathrm{ab}}$ & $38.32^{\mathrm{ab}}$ & $40.44^{\mathrm{a}}$ & $37.43^{\mathrm{b}}$ & $40.98^{\mathrm{a}}$ & $39.73^{\mathrm{ab}}$ & 0.45 \\
\hline \multicolumn{8}{|l|}{ Edible offal's } \\
\hline Liver weight, $g$ & 67.00 & 64.00 & 75.00 & 58.00 & 64.00 & 69.00 & 2.43 \\
\hline Liver, & 2.63 & 2.59 & 3.01 & 2.63 & 2.58 & 2.82 & 0.07 \\
\hline Heart & $8.00^{\mathrm{b}}$ & $8.00^{\mathrm{b}}$ & $11.00^{\mathrm{a}}$ & $8.00^{\mathrm{b}}$ & $8.00^{\mathrm{b}}$ & $8.00^{\mathrm{b}}$ & 0.40 \\
\hline Heart, $\%$ of SW & $0.31^{\mathrm{b}}$ & $0.32^{\mathrm{b}}$ & $0.44^{\mathrm{a}}$ & $0.36^{\mathrm{ab}}$ & $0.32^{\mathrm{ab}}$ & $0.33^{\mathrm{ab}}$ & 0.02 \\
\hline Kidneys weight, $\mathrm{g}$ & $16.00^{\mathrm{b}}$ & $16.00^{\mathrm{b}}$ & $24.00^{\mathrm{a}}$ & $16.00^{\mathrm{b}}$ & $18.00^{\mathrm{ab}}$ & $14.00^{\mathrm{b}}$ & 1.06 \\
\hline Kidneys, $\%$ of SW & $0.63^{\mathrm{b}}$ & $0.65^{\mathrm{b}}$ & $0.96^{\mathrm{a}}$ & $0.73^{\mathrm{b}}$ & $0.73^{\mathrm{b}}$ & $0.57^{\mathrm{b}}$ & 0.04 \\
\hline Testes weight, g & $8.00^{\mathrm{b}}$ & $12.00^{\mathrm{ab}}$ & $13.00^{\mathrm{a}}$ & $9.00^{\mathrm{ab}}$ & $12.00^{\mathrm{ab}}$ & $11.00^{\mathrm{ab}}$ & 0.66 \\
\hline Tests, $\%$ of SW & $0.31^{\mathrm{b}}$ & $0.49^{\mathrm{a}}$ & $0.52^{\mathrm{a}}$ & $0.41^{\mathrm{ab}}$ & $0.48^{\mathrm{a}}$ & $0.45^{\mathrm{ab}}$ & 0.02 \\
\hline Total edible offal's weight, $g$ & $99^{\mathrm{ab}}$ & $100^{\mathrm{ab}}$ & $123^{\mathrm{a}}$ & $91^{\mathrm{b}}$ & $102^{\mathrm{ab}}$ & $102^{\mathrm{ab}}$ & 3.71 \\
\hline Total edible offal's, $\%$ of SW & $3.89^{\mathrm{b}}$ & $4.04^{\mathrm{b}}$ & $4.93^{\mathrm{a}}$ & $4.13^{\mathrm{b}}$ & $4.11^{\mathrm{b}}$ & $4.16^{\mathrm{b}}$ & 0.10 \\
\hline Carcass weight (CW1), g & 1436 & 1426 & 1363 & 1288 & 1361 & 1374 & 32.17 \\
\hline \multicolumn{8}{|l|}{ Carcass weight including edible offal's (CW2) } \\
\hline \multirow{2}{*}{\multicolumn{8}{|c|}{$\mathrm{DP}^{I}(\mathrm{CW} 1 / \mathrm{SW})$}} \\
\hline & & & & & & & \\
\hline \multirow[t]{2}{*}{$\mathrm{DP}^{2}(\mathrm{CW} 2 / \mathrm{SW})$} & $56.42^{\mathrm{ab}}$ & $57.64^{\mathrm{a}}$ & $54.63^{\mathrm{b}}$ & $58.44^{\mathrm{a}}$ & $54.90^{\mathrm{b}}$ & $56.10^{\mathrm{ab}}$ & 0.47 \\
\hline & $60.31^{\mathrm{ab}}$ & $61.68^{\mathrm{ab}}$ & $59.56^{\mathrm{ab}}$ & $62.57^{\mathrm{a}}$ & $59.02^{\mathrm{b}}$ & $60.27^{\mathrm{ab}}$ & 0.45 \\
\hline \multicolumn{8}{|l|}{ Chemical analysis of the 9,10 and $11^{\text {th }}$ ribs } \\
\hline Dry matter & $33.24^{\mathrm{a}}$ & $34.65^{\mathrm{a}}$ & $26.99^{\mathrm{b}}$ & $33.19 \mathrm{a}$ & $31.74^{\mathrm{ab}}$ & $33.45^{\mathrm{a}}$ & 0.82 \\
\hline \multicolumn{8}{|l|}{ Chemical composition on DM basis } \\
\hline Crude prot & 59.25 & 59.93 & 57.72 & 62.69 & 63.33 & 64.32 & 1.17 \\
\hline Ether extract (EE) & 32.83 & 31.99 & 35.32 & 30.28 & 27.74 & 27.50 & 1.30 \\
\hline Ash & $7.92^{\mathrm{ab}}$ & $8.08^{\mathrm{ab}}$ & $6.96^{\mathrm{b}}$ & $7.03^{\mathrm{b}}$ & $8.93^{\mathrm{a}}$ & $8.18^{\mathrm{ab}}$ & 0.22 \\
\hline
\end{tabular}

$a, b, c$ and $d:$ Means in the same row having different superscripts differ significantly $(P<0.05)$.

SEM, standard error of the mean. 
Table 9. Economic evaluation of the experimental groups

\begin{tabular}{|c|c|c|c|c|c|c|c|}
\hline & \multirow{3}{*}{ Item } & \multicolumn{6}{|c|}{ Experimental diets } \\
\hline & & \multicolumn{3}{|c|}{$\begin{array}{l}100 \% \\
\text { Protein requirements }\end{array}$} & \multicolumn{3}{|c|}{$\begin{array}{c}90 \% \\
\text { Protein requirements }\end{array}$} \\
\hline & & $\mathrm{G}_{1}$ & $\mathrm{G}_{2}$ & $\mathrm{G}_{3}$ & \begin{tabular}{l|l}
$\mathrm{G}_{4}$ \\
\end{tabular} & $\mathrm{G}_{5}$ & $\mathrm{G}_{6}$ \\
\hline & Marketing weight, $\mathrm{Kg}$ & 2.057 & 2.242 & 2.396 & 2.087 & 2.300 & 2.419 \\
\hline & Feed consumed / rabbit, kg & 6.006 & 5.488 & 6.013 & 6.223 & 5.698 & 5.768 \\
\hline & Costing of one $\mathrm{kg}$ feed, $(\mathrm{LE})^{1}$ & 2.094 & 2.197 & 2.301 & 1.997 & 2.112 & 2.227 \\
\hline & Total feed cost, (LE) & 12.577 & 12.057 & 13.836 & 12.427 & 12.03 & 12.845 \\
\hline & Management/ Rabbit, $(\mathrm{LE})^{2}$ & 4 & 4 & 4 & 4 & 4 & 4 \\
\hline & Total cost, $(\mathrm{LE})^{3}$ & 31.58 & 31.06 & 32.84 & 31.43 & 31.03 & 31.85 \\
\hline & Total revenue, $(\mathrm{LE})^{4}$ & 45.25 & 49.32 & 52.71 & 45.91 & 50.60 & 53.22 \\
\hline & Net revenue & 13.67 & 18.26 & 19.87 & 14.48 & 19.57 & 21.37 \\
\hline & Economical efficiency $^{5}$ & 0.4329 & 0.5879 & 0.6051 & 0.4607 & 0.6307 & 0.6710 \\
\hline & Relative economic efficiency ${ }^{6}$ & 100 & 135.8 & 139.8 & 106.4 & 145.7 & 155.0 \\
\hline & Feed cost / kg LBW (LE) ${ }^{7}$ & 6.11 & 5.38 & 5.77 & 5.95 & 5.23 & 5.31 \\
\hline \multicolumn{8}{|c|}{${ }^{1}$ Based on prices of year 2010} \\
\hline \multicolumn{8}{|c|}{2 Include medication, vaccines, sanitation and workers. } \\
\hline \multicolumn{8}{|c|}{${ }^{3}$ include the feed cost of experimental rabbit which was LE $15 /$ rabbit + management. } \\
\hline \multicolumn{8}{|c|}{${ }^{4}$ Body weight $x$ price of one $\mathrm{kg}$ at selling which was $L E 22}$. \\
\hline \multicolumn{8}{|c|}{${ }^{5}$ net revenue per unit of total cost. } \\
\hline \multicolumn{8}{|c|}{${ }^{6}$ Assuming that the relative economic efficiency of control diet equal 100.} \\
\hline \multicolumn{8}{|c|}{ Feed cost $/ \mathrm{kg} L B W=$ feed intake $*$ price of $\mathrm{kg} /$ Live weight. } \\
\hline
\end{tabular}

